\title{
Slovanský svět a slavistika v převratné době: několik úvodních reflexí
}

Autoři přítomných studií přemýšlejí o různých věcech, ale jedno mají společné: Slovany, jejich duchovní svět a slavistiku jako komplexní vědu o Slovanech vycházející z filologického jádra. Brněnská slavistika, přesněji Ústav slavistiky Masarykovy univerzity se od roku 1995 stal na poměrně dlouhou dobu epicentrem takových bádání, ale také ohniskem nových snah metodologických a organizačních, dodnes bohužel v realitě do jisté míry neuskutečněných, takřka by se dalo říci, že alespoň dnes neuskutečnitelných, neúspěšných. Autoři se zde zamýšlejí se nad místem slavistiky v převratné době, jsou radikální, krajní, ale také zdrženliví, obrácení k minulosti slavistiky, méně odvážní, ale jinak interpretačně kvalitní, analyzují Dostojevského a jeho neblahé vize světa, jež se dnes bohužel s matematickou přesností uskutečňují, zabývají se výzvami a perspektivami slavistiky, líčí stav slavistiky na svých pracovištích, znovu prověřují kompaktnost slovanského fenoménu, píšou také o mezinárodní organizaci slavistů červivé přežitky minulosti. To, co je však mnohem podstatnější, spočívá v slovanském fenoménu jako takovém: v podstatě se tu objevuje podprahový, spodní proud faktů a intuicí, že slovanský svět je zvláštní, podivuhodně utvářený, nikoli však nějak výlučný; naopak jeho kvalita je tak zřejmá právě proto, že stojí na několikerých kulturních průsečících, že se často stává materiálem pro změnu metodologií, lakmusovým papírkem jejich průkaznosti a flexibility. Sám pojem slovanský svět, Slovanstvo nebo Slované se dnes podrobuje revizi až nenávistné; přitom jde pouze o přirozené vyjádření společných rysů jazykově i jinak spřažených etnik, která měla společnou minulost; jejich vývoj se diverzifikoval, jindy zase konvergoval, odtahovala se od sebe, poté zase sbližovala podle objektivních situací a subjektivních pohnutek, Již vícekrát se zdálo, že tento fenomén je něco překonaného, archaického, škodlivého, že probouzí nezdravý nacionalismus, že směřuje proti Evropě: jeden český slavista to dokonce formuloval tak, že Slované jsou verbeží Evropy. Chápu ten postoj: jistě, Slované neutvářeli ani Imperium Romanum, ani Svatou říši římskou národa německého, nakonec jejich státotvornost je předmětem pochybností a staří kronikáři to jako by potvrzují: kdo stál u kořenů Kyjeva nebo sjednocení západoslovanských kmenů, se žáci tam i onde dovídají již v obecné škole. Nestáli u kolébek ani renesance, ani baroka. Slované představují velkolepý proces rozšiřování, ale také prohlubování, vnitřní kultivace: odtud „zázraky“, tj. nečekané výrony hodnot: to se týká umění obecně a literatury zvláště, nerovnoměrnost vývoje, paradoxní jevy, schopnost imitace, ale také přetváření podnětů, vytváření nových hodnot, to je to, co jsem ve svých studiích o slovanských literaturách, hlavně o ruské, nazval prae-post efektem, tedy schopností nedokonale imitovat, a tak otvírat další „okna“ směřující jinam, vytvářející boční produkty, překonávající staré poetiky. Je možné 
aplikovat tyto slovanské anomálie, nepravidelnosti i na politiku, to by bylo ještě zajímavější, ale slavisté většinou politology nejsou, i když politiku do svých úvah zahrnout musejí.

Slovanský svět je stylizace: jistě jde o pojem vnitřně heterogenní, měňavkovitě historicky proměnlivý, nabývající různých podob, tu se rozpojující, tu se zase spojující, je to pojem neustále se rozpadající a znovu se vytvářející, permanentní proces: to se ovšem týká i pojmu slovanské literatury. Zatímco jazyková identita Slovanů je mimo pochybnost, i když bychom mohli stěží u Čechů nebo Slovinců doložit „slovanský“ ráz struktury jejich jazyků, v prrípadě textových produktů, umění aj. je to hůře viditelné: proto také polemiky vedené například Frankem Wollmanem se skeptickými Poláky, kteří pozapomněli na svůj vlastní panslavismus počátku 19. století, který se stal Kollárovi vzorem. Nemusíme se utopicky stavět za nějakou slovanskou nehybnost, naopak silou slovanského fenoménu je neustálá proměna: to mu dodává sílu. Slované stáli často na čele světového vývoje, byli objektem dějinných experimentů, ale také sami zkoušeli pevnost ideologií a výhledy, plynutí vyzařující z gnóse a buddhismu. Jejich velké teritoriální rozpětí jim umožňuje spojovat Asii a její evropský poloostrov, být dědicem Říma i Byzance, ale také asijských despocií a agresivních kočovníků. I v dnešní přelomové době tu slovanský fenomén stojí jako něco sice zdánlivě odsunutého na vedlejší kolej, ale současně pevného při vší pohyblivosti a proměnlivosti tváří $\mathrm{v}$ tvář jiným civilizačním tlakům a vnitřní evropské degeneraci; dějinná zkušenost Slovanů je silná právě jejich „křižovatkovým“ charakterem, průnikovostí: to může být dost rozhodující právě v době ohrožení nebo radikálního přehodnocování či posunu akcentů. V této době se právě nacházíme. Je tedy zkoumání Slovanů a jejich kulturních produktů, tedy slavistika v širokém slova smyslu, velmi důležitou disciplínou, jejíž význam zatím nepozorovaně, ale o to jistěji stoupá, i když o tom mnozí nevědí nebo vědět nechtějí. Možná se ukáže, že studovat Slovany je stejně důležité, jako se podivovat, obdivovat nebo se bát jiných civilizací. Znalost Slovanů a jejich schopností jako světa stojícího na hranách dějin může být onou mrtvou i živou vodou, jíž se scelí a pak oživí unavené tělo Evropy: je to sice představa takřka mytická spojená s modernou s její ztěžklou, tmavou krví, jak o tom ve svém eseji Devatenácté století psal ruský akméista Osip Mandelštam (http://rvb.ru/mandelstam/01text/vol_2/03prose/2_188.htm, 15. 9. 2016, 21:27), ale její vizionářská síla je doložená konkrétními textovými výstupy. Důležitost slovanského fenoménu si potom řekne i o novou organizaci bádání s jinými lidmi v jeho čele na jiné bázi mezinárodní spolupráce, jejichž přesnou představu již máme. Tyto studie tuto dobu „zlatého věku“ slavistiky pomáhají přibližovat. 